\title{
The Development of Media and Special Event through Cooperative Learning to Raise Funds for Students with Financial Difficulties at Faculty of Industrial Education and Technology
}

\author{
Pornpapatsorn Princhankol ${ }^{1}$ \& Kuntida Thamwipat ${ }^{1}$ \\ ${ }^{1}$ Faculty of Industral Education and Technology, King Mongkut's University of Technology Thonburi, Bangkok, \\ Thailand \\ Correspondence: Pornpapatsorn Princhankol, Faculty of Industral Education and Technology, King Mongkut's \\ University of Technology Thonburi, Bangkok, Thailand. Tel: 662-4708-5656. E-mail: \\ pornpapatsorn.pri@kmutt.ac.th
}

Received: June 26, 2018

doi:10.5539/ies.v11n11p88
Accepted: July 31, $2018 \quad$ Online Published: October 29, 2018

URL: https://doi.org/10.5539/ies.v11n11p88

\begin{abstract}
This research was aimed (a) to develop media and special event through cooperative learning to raise funds for students with financial difficulties at Faculty of Industrial Education and Technology, (b) to evaluate the quality of such media and special event, (c) to measure the learning achievements and the satisfaction of students towards cooperative learning, and (d) to measure the satisfaction of participants in such event. This research was both quantitative and qualitative. There were two sampling groups in this study. The first group consisted of 34 students who enrolled in the ETM 361 Presentation Skills II course in the second semester of the academic year 2017. The second group consisted of 297 participants in the event. The statistical analysis included means score, standard deviation and dependent t-test for research hypothesis testing. The results from the quantitative analysis showed that the quality of the contents was at a very good level $(x=4.90$, S.D. $=0.17)$ and the quality of the media and special event was at a very good level $(\bar{x}=4.71$, S.D. $=0.43)$. The cooperative learning consisted of 6 stages as in 1$)$ examining problems, 2) planning, 3) implementing, 4) reviewing and follow-up, 5) practicing and presentation, and 6) reflection and evaluation. The learning achievements of students through cooperative learning showed that their average post-test score was higher than their average pre-test score with a statistically significant difference at the. 05 level. The cooperative learning increased the teamwork among the students. The students expressed the highest level of satisfaction towards the cooperative learning $(\bar{x}=4.76$, S.D. $=0.42)$. The participants expressed a high level of satisfaction towards the event $(x=4.43$, S.D. $=0.63)$. The most common problem during the event was lack of communications among students and it could be resolved by the use of social network or closed group on Facebook to report activities and follow-up. The benefit from this event was that the students spent more time working for others and therefore their service mind increased. It could be concluded that the media and special event through cooperative learning could be used on future occasions.
\end{abstract}

Keywords: media and special event, fund-raising for students with financial difficulties, cooperative learning

\section{Introduction}

Active learning is a teaching approach which Faculty of Industrial Education and Technology considers to be important for instruction. Learners are given problems to think and resolve in real situations. One element of active learning is cooperative learning in that learners need to cooperate with others and help others to become responsible and accountable to each member in the group. Learners are expected to work in groups and analyze their learning together through discussions. Active learning is suitable for a special event in various courses offered by Faculty of Industrial Education and Technology (Toomtong, 2012).

Faculty of Industrial Education and Technology, King Mongkut's University of Technology Thonburi (KMUTT), was established in 1966. In 2016, it has marked the fiftieth anniversary (Faculty of Industrial Education and Technology, 2018). Over the past fifty years, there have been many students who have worked hard and developed themselves during their four and five years of study. Besides their academic studies and extracurricular activities, it's important to address the quality of life for students so that they can succeed in both areas. However, in reality, there are still some students who suffer from financial difficulties and family issues, resulting in their lack of 
opportunities in education.

For many years, a large number of students at the Faculty of Industrial Education and Technology have received funding through fund-raising activities. Each student suffered from different issues such as fire, flooding, or lack of money. If they need to wait for the approval by the university, it might be too late. Faculty of Industrial Education and Technology has set up some fund for this group of students through fund-raising activities organized by fourth-year students who enrolled in the ETM 361 Presentation Skills II course (Thamwipat, 2018). These activities started in 2008 and they have been held every year since then so that the fund would go to the funding body. Moreover, these activities promote service mind and bond between faculty members and students in all seven departments of the faculty. In the second semester of the academic year 2017, there was a concert held by the students to raise funds for students with financial difficulties with the title "FIET Music Lovers: Blue Heart" so that students with financial difficulties could come for support. In these activities, the students needed to cooperate in order to think about activities and discuss their ideas for various types of activities. In the ETM 361 Presentation Skills II course, the instruction has followed an active learning approach for over five years. Now, the researchers would like to evaluate the learning achievements as well as the satisfaction of the students towards the active learning approach.

\subsection{Objectives}

The objectives of this research were as follows:

1) To develop media and special event through cooperative learning to raise funds for students with financial difficulties at Faculty of Industrial Education and Technology

2) To evaluate the quality of the media and special event through cooperative learning to raise funds for students with financial difficulties at Faculty of Industrial Education and Technology

3) To measure the learning achievements and the satisfaction of the students towards the cooperative learning approach as well as to measure the satisfaction of the participants in the event to raise funds for students with financial difficulties at Faculty of Industrial Education and Technology

\subsection{Research Hypotheses}

The hypotheses of this research were as follows:

1) The quality of the media and special event through cooperative learning to raise funds for students with financial difficulties at Faculty of Industrial Education and Technology would be at a good level.

2) The learning achievements of the students through cooperative learning would show that their average post-test score was higher than their average pre-test score with a statistically significant difference at the .05 level.

3) The satisfaction of the students towards cooperative learning would be at a high level and the satisfaction of the participants towards the special event to raise funds for students with financial difficulties would be at a high level.

\subsection{Expected Outcomes}

The expected outcomes of this research were as follows:

1) The students would develop their cooperative skills and their service mind.

2) The students could apply their classroom knowledge for social service.

3) This research would be a basis for the development of active learning for students.

\subsection{Research Scope}

\subsubsection{Population}

The population in this research consisted of 2 groups as follows:

1) 95 fourth-year students at Department of Educational Communications and Technology

2) Around 600 participants in the special event organized by the students

\subsubsection{Sampling Group}

There were 2 sampling groups for quantitative data in this study as follows:

1) There were 34 fourth-year students who enrolled in the ETM 361 Presentation Skills II course in the second semester of the academic year 2017. They were chosen using purposive sampling method.

2) There were 297 academic staff members, parents and students who participated in the questionnaire survey.

The sampling group for qualitative data consisted of 34 fourth-year students who enrolled in the ETM 361 
Presentation Skills II course in the second semester of the academic year 2017. The questions for the semi-structured interview were as follows:

- What are the problems which you encounter during the special event to raise funds for students with financial difficulties? How do you resolve these problems?

- What do you think about cooperative learning?

- What do you learn from this special event?

\subsubsection{Expert Panels}

The experts were those with knowledge and expertise in assessing the quality of the media and special event to raise funds for students with financial difficulties at Faculty of Industrial Education and Technology. They were chosen using purposive sampling method out of those who were experts in this field and were willing to evaluate the quality of the media and activities. There were 3 panels of experts as follows:

1) Experts in contents were those with at least a Master's degree or knowledge and expertise in cooperative learning for over 5 years. There were 3 experts in contents.

2) Experts in media and activities were those with at least a Master's degree or knowledge and expertise in the development of media and activities. There were 3 experts in media and activities.

3) Experts in measurements and evaluation were those with at least a Master's degree or at least 5 years of working experience in assessing the IOC value of questionnaires, surveys and interviews. There were 3 experts in measurements and evaluation.

\subsection{Research Tools}

The research tools in this study were as follows:

1) Media and special event to raise funds for students with financial difficulties at Faculty of Industrial Education and Technology

2) The questionnaires to evaluate the quality of contents and the quality of media and special event with Likert's 5-rating scale varying from the highest, high, moderate, low and the lowest (Srisa-ard, 2010)

3) The learning achievement test and the satisfaction questionnaire for students regarding the cooperative learning approach. The questionnaire items followed Likert's 5-rating scale varying from the highest, high, moderate, low and the lowest (Srisa-ard, 2010)

4) The semi-structured interview schedule regarding the attitudes of students towards the cooperative learning approach and the special event.

\subsection{Data Analysis}

The data were analyzed using the following statistical methods: mean score, standard deviation, dependent t-test and descriptive data analysis.

\subsection{Research Results}

1.7.1 The Results from the Development of Media and Special Event to Raise Funds for Students with Financial Difficulties

The media and special event to raise funds for students with financial difficulties at Faculty of Industrial Education and Technology were developed according to the following steps as shown in Table 1. 
Table 1. Steps in the Development of Media and Special Event 4 P's (Lani Arredondo, 1994)

\begin{tabular}{|c|c|}
\hline Step & escription \\
\hline Plan & $\begin{array}{l}\text { The researchers examined the possibilities and wrote a proposal to ask for budget from the Faculty and then designed posters and } \\
\text { brochures to promote the concert "FIET Music Lover: Blue Heart". The theme was about love from everybody in the faculty to } \\
\text { participate in the concert. There were } 6 \text { periods of love songs. }\end{array}$ \\
\hline Prepare & $\begin{array}{l}\text { The posters were designed for } 6 \text { periods and these were uploaded to the main webpage of the faculty.They prepared the music hall, } \\
\text { audio visual, script, teamwork, etc. }\end{array}$ \\
\hline Present & $\begin{array}{l}\text { Representatives from each department participated in the fund-raising event by becoming models and performers. The students } \\
\text { promoted the special event on social media network Facebook by sharing the links. They could run the concert "FIET Music Lover: } \\
\text { Blue Heart" on time. }\end{array}$ \\
\hline Proceed & $\begin{array}{l}\text { Every week the students reported their progress in the classroom and on the social media network, or Facebook, with the group } \\
\text { ETM } 361 / 2560 \text { so that everybody was aware of the progress as well as the issues and could help resolve any issues. } \\
\text { The students worked as a team to discuss the issues, to solve the problems and to make suggestions. }\end{array}$ \\
\hline
\end{tabular}

The media and special event to raise funds for students with financial difficulties "FIET Music Lovers" with 6 periods of love songs were shown in Figure 1.

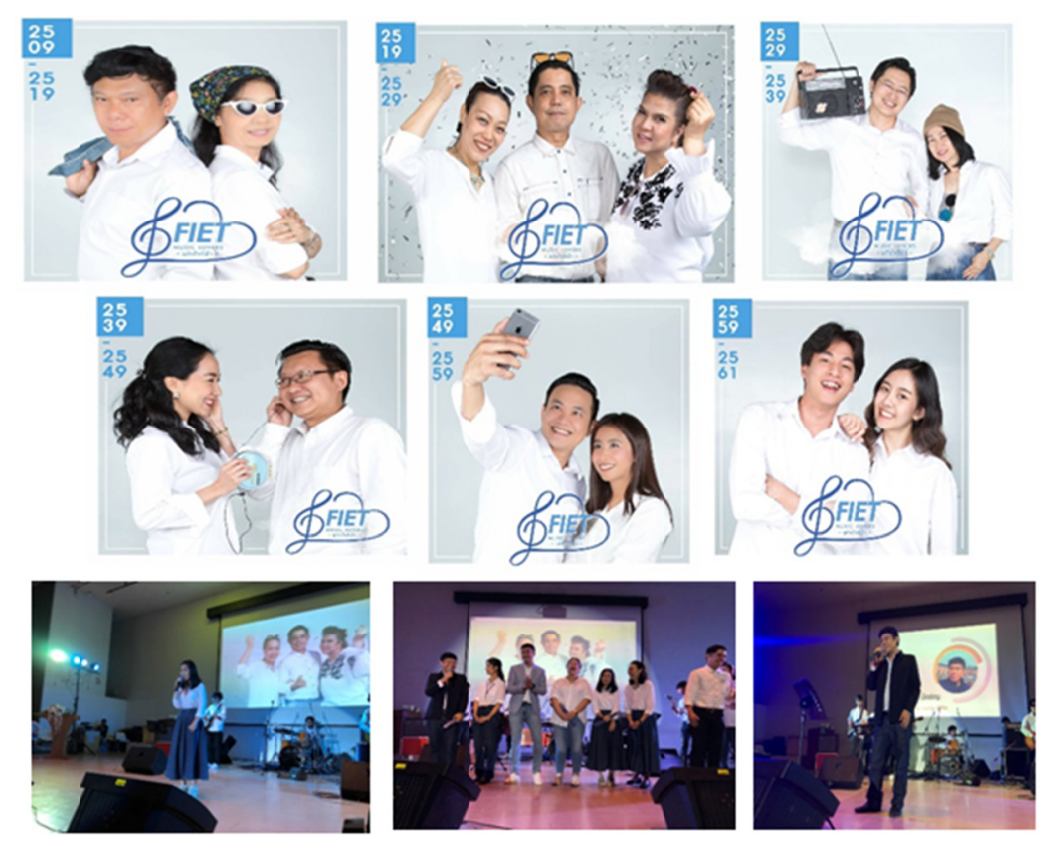

Figure 1. Posters and photos of FIET music lovers

\subsubsection{The Quality of the Media and Special Event to Raise Funds for Students with Financial Difficulties}

The media and special event to raise funds for students with financial difficulties at Faculty of Industrial Education and Technology were evaluated by the experts and shown in the table below.

Table 2. Quality of the media and special event as evaluated by the experts

\begin{tabular}{lccc}
\hline Item & Mean & S.D. & Meaning \\
\hline Quality of contents evaluated by the experts in contents & 4.90 & 0.17 & Very Good \\
Quality of media and special event evaluated by the experts in media and activities & 4.71 & 0.43 & Very Good \\
\hline
\end{tabular}

The results from the quality evaluation by the experts showed that the quality of the media was at a very good level $(\bar{x}=4.90$, S.D. $=0.17)$ and the quality of the media and special event was at a very good level $(\bar{x}=4.71$, S.D. $=0.43)$. The results confirmed the research hypothesis. 
Table 3. Stages in the cooperative learning approach

\begin{tabular}{|c|c|}
\hline Step & tivities \\
\hline 1. Planning & $\begin{array}{l}\text { The students divided themselves into groups and assigned each group a task. There were } 8 \text { groups as in administration, } \\
\text { public relations, sales, finance, collaboration, performance academic and location. }\end{array}$ \\
\hline $\begin{array}{l}2 . \\
\text { Implementing }\end{array}$ & $\begin{array}{l}\text { The media and activities were designed by asking each department to participate as models or to sell tickets to parents. The } \\
\text { funds were raised both inside and outside the faculty. }\end{array}$ \\
\hline 3. Reviewing & $\begin{array}{l}\text { two phases done by the students. The first phase was the public relations as well as ticket sales. The second phase } \\
\text { performance and concert. The students reported their progress in the class every week as well as on the closed } \\
\text { roup. }\end{array}$ \\
\hline 4. Presentation & $\begin{array}{l}\text { The promotional material was posted on the main web page of the fund-raising event and the half-day concert was held on } \\
\text { the 30th of April, } 2018 \text {. }\end{array}$ \\
\hline 5. Evaluation & $\begin{array}{l}\text { The researchers and the students evaluated the performance, as a whole and by sub-group. The evaluations were from the } \\
\text { students themselves, the participants and the researchers. }\end{array}$ \\
\hline
\end{tabular}

1.7.3 The Learning Achievements and Satisfaction of the Students towards the Cooperative Learning Approach

The learning achievements of the students showed that their average post-test score was higher than their average pre-test score with a statistically significant difference at the. 05 level. The satisfaction of the students towards the cooperative learning approach was at the highest level $(\bar{x}=4.76$, S.D. $=0.42)$. The satisfaction of the participants was at a high level $(x=4.43$, S.D. $=0.63)$. The results confirmed the research hypothesis.

Table 4. Findings from the interview with students who participated in the special event

\begin{tabular}{ll}
\hline Issue & Solution \\
\hline $\begin{array}{l}\text { 1. Lack of communications between } \\
\text { groups }\end{array}$ & $\begin{array}{l}\text { The students reported their progress in classroom and on the Facebook closed group. The researchers } \\
\text { supervised the students frequently. } \\
\text { 2. Lack of free time during the first } \\
\text { phase of fund-raising }\end{array}$ \\
$\begin{array}{l}\text { The students in the same group did not have the same free time. Therefore, the students from other } \\
\text { groups who were free had to help so that the work went according to the plan. } \\
\text { during the first phase }\end{array}$ & $\begin{array}{l}\text { Everybody including academic staff members, students from many departments, alumni and students } \\
\text { from the Student Council needed to come forward to help with the concert. }\end{array}$ \\
\hline
\end{tabular}

The attitudes of the students towards the cooperative learning approach were that they were satisfied with it because this type of instruction was active learning. It was not boring. They could use their knowledge in real situations. They could also help students with financial difficulties. Everybody learned to be responsible and they had a chance to express their opinion as well as their reflections. They helped each other and they learned by collaboration. They talked to each other and they were more cooperative.

The benefit which the students gained from the cooperative learning approach was the teamwork through collaboration between staff members, alumni and current students as well as parents who participated in the special event to raise funds for students with financial difficulties at Faculty of Industrial Education and Technology. This increased their service mind and they spent more time working for others. They had increased their teamwork and they could apply their knowledge from every subject in real use.

\subsubsection{The Satisfaction of the Participants towards the Special Event Organized by the Students}

The satisfaction of the participants towards the special event organized by the students was at a high level $(\bar{x}$ $=4.43$, S.D. $=0.63$ ). The results confirmed the research hypothesis.

\section{Research Discussion}

The research study into the development of media and special event to raise funds for students with financial difficulties at Faculty of Industrial Education and Technology followed the cooperative learning concept proposed by Kagan (1995) which consists of 6 elements as in team, will, management, social skill and 4 basic principles which are Positive Interdependence, Individual Accountability, Equal Participation and Simultaneous Interaction (PIES). The concept is similar to the one proposed by Laoreandee (2004) in that cooperative learning helps learners to learn and engage in activities to achieve the target goal. To do so, each member needs to be responsible so that they can achieve the goal. They learn to express and share opinions and they depend on each other to help and learn. Therefore, they learn by cooperation. The development of media and activities was also based on ADDIE Model (Santajit, 2013) which consists of Analysis, Design, Development, Implementation and 
Evaluation. Each stage of the research was supervised by the experts so that they could evaluate the quality of the contents, the media and special and the measurements as well as the evaluation. The results from this study showed that the quality of the media and special event was at a very good level $(\bar{x}=4.71$, S.D. $=0.43)$. The results were similar to the ones in the study into the development of digital multimedia and special events for the funding of poor students on the occasion of the 50th anniversary for Faculty of Industrial Education and Technology, King Mongkut's University of Technology Thonburi (Princhankol, Thamwipat, \& Duangrit, 2017) in that the quality of the contents was at a very good level $(\bar{x}=4.86$, S.D. $=0.23)$ and the quality of the media and activities was at a very good level $(\bar{x}=4.69$, S.D. $=0.44)$.

The learning achievements of the students showed that their average post-test score was higher than the average pre-test score with a statistically significant difference at the.05 level. The satisfaction of the students towards cooperative learning was at the highest level $(\bar{x}=4.76$, S.D. $=0.42)$. The results confirmed the research hypothesis and were similar to the research by Lekjaroen and Ruamsuk (2013) who conducted a comparison of the achievement of Prathomsuksa One students on word spelling abilities taught by using cooperative learning TGT technique and conventional method in that the learning achievements of the students after the instruction were higher than the pre-test score with a statistically significant difference at the. 05 level. The satisfaction of the students was at a high level.

\section{Suggestions}

\subsection{Suggestions from the Research Results}

1) The IT technology should be used such as social media network or Facebook for communication between instructors and students. The use of Facebook closed group is useful for the progress and both instructors and students can collaborate better.

2) To make cooperative learning successful, instructors need to work as coaches for students. Coaches need to supervise and give advice to students at every stage of the study. Moreover, students need to report their progress and collaborate online frequently so that others can follow and when there are problems, instructors can help them immediately.

3) To develop media and activities as well as a special event, instructors and students need to plan together and they need to review each activity frequently. Students need to have support at each stage of the special event as well.

\subsection{Suggestion for Further Research}

1) There should be a development of media and special event in other topics to raise funds for students with financial difficulties at Faculty of Industrial Education and Technology.

2) There should be a study into the analysis of factors which affect an online collaborative learning approach.

\section{Acknowledgments}

The researchers would like to acknowledge the funding for cultural activities from Faculty of Industrial Education and Technology, King Mongkut's University of Technology Thonburi.

\section{References}

Arredondo, L. (1994). Business Presentation. New York: McGraw-Hill Inc.

Faculty of Industrial Education and Technology. (2018). History, Vision, Mission. Retrieved from http://FIET.kmutt.ac.th/

Kagan, S. (1995). Cooperative Learning Resources for Teacher. New Jersey: Englewood Cliffs.

Laoreandee, W. (2004). Learning Techniques for Professional Teachers: Manual and Instructional Material. Nakornprathom: Faculty of Education, Silpakorn University.

Lekjaroen, S., \& Ruamsuk, S. (2013). A Comparison of the Achievement of Prathomsuksa One Students on Word Spelling Abilities Taught by Using Cooperative Learning TGT Technique and Conventional Method. Silpakorn Education Research Journal, 5(1), 132-141.

Princhankol, P., Thamwipat, K., \& Duangrit, P. (2017, April). The Development of Digital Multimedia and Special Events for the Funding of Poor Students on the Occasion of 50th Anniversary for Faculty of Industrial Education and Technology, King Mongkut's University of Technology Thonburi. 3rd International Conference on Education and Distance Learning 2017. Galle Face Hotel, Colombo, Srilanka.

Santajit, J. (2013). ADDIE MODEL. Retrieved from http://www.gotoknow.org/posts/520517

Srisa-ard, B. (2010). Basic Research. Bangkok: Suweeriyasarn Publishing. 
Thamwipat, K. (2018). Interview [29 January 2018].

Toomtong, B. (2012). Research Methods for Curriculum and Instruction. Nakornratchasima: Laemtong Printing.

\section{Copyrights}

Copyright for this article is retained by the author(s), with first publication rights granted to the journal.

This is an open-access article distributed under the terms and conditions of the Creative Commons Attribution license (http://creativecommons.org/licenses/by/4.0/). 